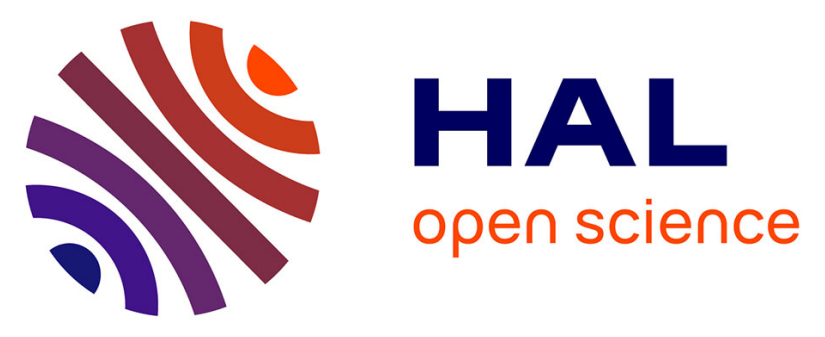

\title{
The changes in the contents of health-promoting compounds and antioxidant activity of broccoli upon domestic processing
}

Anna Gliszczyńska-Świglo, Ewa Ciska, Katarzyna Pawlak-Lemańska, Jaroslaw Chmielewski, Tomasz Borkowski, Bożena Tyrakowska

\section{To cite this version:}

Anna Gliszczyńska-Świglo, Ewa Ciska, Katarzyna Pawlak-Lemańska, Jaroslaw Chmielewski, Tomasz Borkowski, et al.. The changes in the contents of health-promoting compounds and antioxidant activity of broccoli upon domestic processing. Food Additives and Contaminants, 2006, 23 (11), pp.1088-1098. 10.1080/02652030600887594 . hal-00577498

\section{HAL Id: hal-00577498 \\ https://hal.science/hal-00577498}

Submitted on 17 Mar 2011

HAL is a multi-disciplinary open access archive for the deposit and dissemination of scientific research documents, whether they are published or not. The documents may come from teaching and research institutions in France or abroad, or from public or private research centers.
L'archive ouverte pluridisciplinaire HAL, est destinée au dépôt et à la diffusion de documents scientifiques de niveau recherche, publiés ou non, émanant des établissements d'enseignement et de recherche français ou étrangers, des laboratoires publics ou privés. 


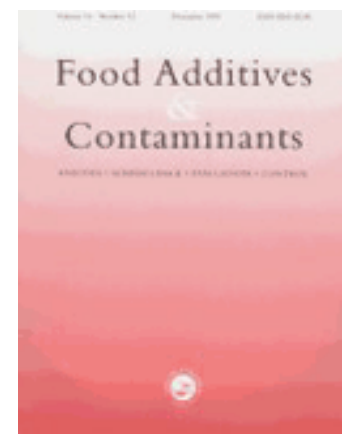

\section{The changes in the contents of health-promoting compounds and antioxidant activity of broccoli upon domestic processing}

\begin{tabular}{|r|l|}
\hline Journal: & Food Additives and Contaminants \\
\hline Manuscript ID: & TFAC-2005-374.R2 \\
\hline Manuscript Type: & Original Research Paper \\
\hline Date Submitted by the & 14-Jun-2006 \\
\hline Complete List of Authors: & $\begin{array}{l}\text { Gliszczyńska-Świgło, Anna; The Poznañ University of Economics, } \\
\text { Faculty of Commodity Science } \\
\text { Ciska, Ewa; Polish Academy of Sciences, The Institute of Animal } \\
\text { Reproduction and Food Research } \\
\text { Pawlak-Lemańska, Katarzyna; The Poznañ University of Ecinomics, } \\
\text { Faculty of Commodity Science } \\
\text { Chmielewski, Jarosław; The Poznañ University of Economics, } \\
\text { Faculty of Commodity Science } \\
\text { Borkowski, Tomasz; The Poznañ University of Ecinomics, Faculty of } \\
\text { Commodity Science } \\
\text { Tyrakowska, Bożena; The Poznañ University of Economics, Faculty } \\
\text { of Commodity Science }\end{array}$ \\
\hline Food Types: & $\begin{array}{l}\text { Vegetables } \\
\text { Chromatographic analysis }\end{array}$ \\
\hline Methods/Techniques: & \begin{tabular}{l} 
Antioxidants \\
\hline Contaminants:
\end{tabular} \\
\hline \hline
\end{tabular}

\section{SCHOLARONE ${ }^{\text {w }}$ Manuscripts}


1 Changes in the content of health-promoting compounds and 2 antioxidant activity of broccoli after domestic processing

3

4 5

6 7 8 9 10

\section{ANNA GLISZCZYŃSKA-ŚWIGLO ${ }^{1}$, EWA CISKA ${ }^{2}$, KATARZYNA}

PAWLAK-LEMAŃSKA ${ }^{1}$, JAROSŁAW CHMIELEWSKI ${ }^{1}$, TOMASZ BORKOWSKI ${ }^{1}$

\& BOŻENA TYRAKOWSKA ${ }^{1}$

${ }^{1}$ Faculty of Commodity Science, The Poznań University of Economics, al. Niepodległości 10, 60-967 Poznań, Poland

${ }^{2}$ The Institute of Animal Reproduction and Food Research, Polish Academy of Sciences, ul. Tuwima 10, P.O. Box 55, 10-747 Olsztyn, Poland

Address for correspondence: Anna Gliszczyńska-Świgło

Faculty of Commodity Science

The Poznań University of Economics

al. Niepodległości 10

60-967 Poznań,

Poland

Phone: +48618569368

Fax: +48 618543993

e-mail: a.gliszczynska-swiglo@ae.poznan.pl 
1 Abstract

2 The effect of water- and steam-cooking on the content of vitamin C, polyphenols, carotenoids, 3 tocopherols and glucosinolates as well as on the antioxidant activity of broccoli are reported.

4 Flavonoids, phenolic acids, vitamin $\mathrm{C}$ and $\mathrm{E}, \beta$-carotene, lutein, and glucosinolates in 5 domestically processed broccoli were quantified using HPLC methods; total polyphenols 6 were determined with Folin-Ciocalteu reagent. The antioxidant capacity of broccoli extracts 7 were evaluated using the Trolox Equivalent Antioxidant Capacity (TEAC) and 2,2-diphenyl8 1-picrylhydrazyl (DPPH) methods. The results indicated that steam-cooking of broccoli 9 results in an increase in polyphenols, as well as the main glucosinolates and their total content 10 as compared to fresh broccoli, whereas cooking in water has opposite effect. Steam cooking 11 of broccoli has no influence on vitamin $\mathrm{C}$, whereas cooking in water significantly lowers its 12 content. Both, water- and steam-cooking of broccoli results in an increase in $\beta$-carotene, 13 lutein, $\alpha$ - and $\gamma$-tocopherols as compared to fresh broccoli. Similar effects of steaming and 14 water-cooking of broccoli on their antioxidant activity were observed.

16 Keywords: broccoli, polyphenols, vitamin C, carotenoids, tocopherols, glucosinolates, 17 antioxidant activity, domestic processing 
3 Epidemiological data show that a diet rich in cruciferous vegetables such as broccoli, Brussels 4 sprouts, cabbage, cauliflower and kale can significantly reduce the risk of certain forms of cancer (Kohlmeier et al. 1997). The mechanism underlying the reduction of cancer by cruciferous vegetables is not clear, however, it is well known that these vegetables are rich in different health-promoting compounds including the antioxidant vitamin $\mathrm{C}$ and $\mathrm{E}$, polyphenols, glucosinolates, carotenoids and minerals.

Polyphenols are a large group of compounds, which includes flavonoids and phenolic acids.

11 Recently, polyphenols are of increased scientific interest because of their protective effects 12 against cardiovascular, photosensitivity-related diseases, aging, and various forms of cancer. 13 They may act as antioxidants or as agents in other mechanisms contributing to 14 cardioprotective or anticarcinogenic effects (Middleton et al. 1994, Samman et al. 1998).

16 Another health-promoting compound with antioxidant activity is ascorbic acid. Vitamin C is considered a most important water-soluble antioxidant present in the extracellular and intracellular spaces in most biological systems where it can participate in redox reactions. It can also directly scavenge superoxide radical, singlet oxygen, hydrogen peroxide and hydroxyl radical. It is considered that the main contribution of vitamin $\mathrm{C}$ as a lipid peroxidation chain-breaking agent is its ability to regenerate membrane-bound oxidised vitamin E (Kaur et al. 2001).

Also carotenoids posses a range of important biological activities. Some carotenoids e.g. $\alpha-$ carotene, $\beta$-carotene and $\beta$-cryptoxanthine posses pro-vitamin $\mathrm{A}$ activity and they are converted to retinal by mammals. Lutein and zeaxanthin are known to provide protection against age-related macular degeneration, mediated by their ability to quench single oxygen and blue light in the retina (Landrum et al. 2001). Carotenoids are also potent antioxidants and free radical scavengers, playing a role in the prevention of coronary heart disease (Kritchevsky 1999) and in the reduction of risk of developing lung cancer (Block et al. 1992).

Carotenoids are biosynthetically related to other secondary metabolites such as tocopherols. 33 Vitamin E is well accepted as the most effective natural lipid-soluble antioxidant protecting 34 biological membranes, lipoproteins and fat deposit from peroxidative damage. It has been 
1 suggested that it helps to protect against cancer induced by free-radical-generating 2 contaminants such as ozone or nitrogen dioxide. Reduction in the risk of coronary heart 3 diseases associated with a high intake of vitamin $\mathrm{E}$ has also been indicated (Janero 1995, 4 Duell 1996).

Glucosinolates are a group of natural compounds present in especially cruciferous vegetables.

They are responsible for the pungent odour and biting taste of these vegetables. Recently, glucosinolates are of great scientific interest because of their potential protection against the lung, stomach and colon cancers (Murillo et al. 2001). Glucosinolates themselves exhibit minimal anticancer activity, however on chopping, crushing, or chewing the enzyme myrosinase is released and it converts glucosinolates to isothiocyanates, thiocyanates, nitriles, and the number of indolic compounds, including: indole-3-carbinol and products of its oligomerisation, ascorbigens, as well as indole-3-acetonitrile and indole-3-acetic acid (Preobrazhenskaya et al. 1993, Bjergegaard et al. 1994). Some of these products have been reported to protect cells against cancer (Faulkner et al. 1998). Several mechanisms have been proposed for cancer prevention by hydrolysis products of glucosinolates, however the most

It is known that processing may affect, to a significant extent, the concentration and biological activities of different compounds present in plants. This aspect seems to be very important taking into account that only some vegetables are consumed in a raw state and most of them are processed before consumption. Broccoli belongs to vegetables that are usually heat-treated before eating thus it is important to know, which type of domestic processing is the best for preserving health-promoting compounds present in this vegetable. To our knowledge, there is no report discussing the changes in the contents of various groups of health-promoting compounds in broccoli as an effect of different cooking methods. The literature data on the changes in the content of different compounds in broccoli upon domestic processing concern mostly one (e.g. carotenoids) or two (e.g. glucosinolates and vitamin C), rarely three different groups of compounds (Lessin et al. 1997, Price et al. 1998, Vallejo et al. 2002, Zhang et al. 2004, Turkmen et al. 2005). Thus, the present study was undertaken to evaluate the effect of domestic processing such as water- and steam-cooking on the contents of polyphenols, vitamin $\mathrm{C}$ and $\mathrm{E}$, carotenoids and glucosinolates in broccoli as well as on its antioxidant 
1 activity, especially because the data on changes of these compounds during cooking are still

2 limited and sometimes contradictory.

4 Materials and methods

\section{$5 \quad$ Materials}

6 Lutein from Roth (Karlsruhe, Germany), 2,2-diphenyl-1-picrylhydrazyl (DPPH), $\gamma$ 7 tocopherol, $p$-coumaric, ferulic and sinapic acids from Sigma (St. Louis, MO, USA), ABTS 8 (2,2'-azino-bis(3-ethylbenzothiazoline-6-sulfonic acid) diammonium salt from Roche 9 Diagnostics (Mannheim, Germany), quercetin dihydrate, kaempferol and tertbutylhydroquinone (TBHQ) from Fluka (Buchs, Switzerland), Trolox ${ }^{\circledR}, \alpha$-tocopherol, all11 trans- $\beta$-carotene, thero-1,4-dimercapto-2,3-butandiol (DTT) and caffeic acid from Aldrich 12 (Steinheim, Germany), ascorbic acid (vitamin C) from Merck (Darmstad, Germany), 13 isorhamnetin from Extrasynthese, (Genay, France) were used for the study. HPLC-grade 14 solvents and analytical grade reagents (or better) were used for all purposes.

\section{Sample preparation}

17 Broccoli of the Lord cultivar planted in April and harvested at optimal maturity in June 2004 18 was purchased from local farm less than 24 hours before sample preparation. The florets were 19 separated from the main stem and cut into pieces. Two 300-g portions of the florets of 20 broccoli were cooked in a food steamer (model PokyStreamer) for 10 min under atmospheric 21 pressure and in $1000 \mathrm{ml}$ of boiling water for $5 \mathrm{~min}$ and then appropriate samples were 22 combined. Samples were allowed to stand at room temperature, under open air, for $15 \mathrm{~min}$. 23 Subsamples of fresh, steamed and water-cooked broccoli were taken and immediately 24 analysed for vitamin $\mathrm{C}$ content. The rest of plant material was immersed in liquid nitrogen, 25 freeze-dried and dry weight was determined. The dry weight of fresh and processed broccoli 26 was found to be not significantly different. Water after broccoli cooking was also collected. 27 All samples were stored at $-20^{\circ} \mathrm{C}$ under nitrogen generally no longer than two weeks until analysis. Before analyses, lyophilized samples were grounded into a powder.

\section{Extraction and determination of polyphenols}

31 Polyphenols were extracted twice from $2 \mathrm{~g}$ of the dry powder (in triplicate) with $70 \%$ 32 methanol $(50 \mathrm{ml})$ in ultrasonic bath for $15 \mathrm{~min}$. The combined fractions were filtered, 33 evaporated in vacuum at $40^{\circ} \mathrm{C}$ to approximately $20 \mathrm{ml}$ and made up to $25 \mathrm{ml}$ with water (Price 
1 et al. 1998). Concentration of flavonols present in broccoli, which occur as quercetin, 2 kaempferol and isorhamnetin $O$-glycosides were determined after their acid hydrolysis to 3 quercetin, kaempferol and isorhamnetin. Alkaline hydrolysis was done to determine 4 conjugated phenolic acids. For the determination of flavonols and phenolic acids after acid and alkaline hydrolysis, polyphenols were extracted with $70 \%$ methanol containing TBHQ $(0.2 \%)$. Acid and alkaline hydrolysis of polyphenols was performed as described in literature with minor modifications (Vallejo et al. 2004). Acid hydrolysis was performed by adding 1 $\mathrm{ml} 4 \mathrm{~N} \mathrm{HCl}$ to $1 \mathrm{ml}$ of phenolic extract and this solution was incubated in a stoppered test tube for 2 hours at $85^{\circ} \mathrm{C}$. Before HPLC analysis, all samples were centrifuged at $12.000 \mathrm{~g}$ for 5 min. Alkaline hydrolysis was carried out by adding $1 \mathrm{ml} 4 \mathrm{~N} \mathrm{NaOH}$ to $1 \mathrm{ml}$ of polyphenolic extract and keeping the mixture for $20 \mathrm{~h}$ at room temperature in a stoppered test tube under $\mathrm{N}_{2}$ atmosphere. After this time, the alkaline hydrolysis products were acidified with concentrated $\mathrm{HCl}$ down to $\mathrm{pH}$ 1-2 and directly analysed using HPLC.

HPLC analyses were performed at room temperature on Waters 600 high performance liquid chromatograph equipped with Symmetry $\mathrm{C}_{18}$ column $(3.9$ x $150 \mathrm{~mm}, 5 \mu \mathrm{m}$, Waters, Millford, Ma, USA) protected with a Symmetry $\mathrm{C}_{18}$ guard column. Mobile phase, published by Crozier et al. (1997), of acetonitrile (A) and water adjusted to $\mathrm{pH} 2.5$ with trifluoroacetic acid (B) was used according to the modified gradient: linear increment starting with $10 \%$ A to $26 \% \mathrm{~A}$ in 20 min, isocratic $26 \% \mathrm{~A}$ in $5 \mathrm{~min}$, linear gradient from $26 \% \mathrm{~A}$ to $35 \% \mathrm{~A}$ in the next $5 \mathrm{~min}$, and the return to the initial conditions within the next $10 \mathrm{~min}$ with flow rate $1 \mathrm{ml} / \mathrm{min}$. Flavonoids and phenolic acids were detected using a Waters 996 photodiode-array detector set at $370 \mathrm{~nm}$ and $320 \mathrm{~nm}$, respectively. Quercetin, kaempferol, isorhamnetin, caffeic, p-coumaric, ferulic/sinapic acids were identified on the basis of their absorption spectra and retention times compared with those of standards. Quantification of flavonoids and phenolic acids was done using calibration curve prepared for quercetin and sinapic acid, respectively.

\section{Determination of total polyphenols}

29 Total polyphenols were determined by the Folin-Ciocalteu method (Singleton et al. 1965) 30 using gallic acid as the standard. The results are expressed in mg of gallic acid equivalents per $31 \quad 100 \mathrm{~g}$ of dry and fresh weight of broccoli. 
1 Extraction and determination of vitamin $C$

2 Extraction of vitamin C was performed essentially as described by Kurilich et al. (1999).

3 Briefly, $0.500 \mathrm{~g}$ of broccoli was extracted (in triplicate) with $2 \mathrm{ml}$ of $1 \%$ meta-phosphoric 4 acid in ultrasonic bath for $15 \mathrm{~min}$. Then, additional $1 \mathrm{ml}$ of meta-phosphoric acid was added, 5 the mixture was sonicated for the next $15 \mathrm{~min}$ and made up to $5 \mathrm{ml}$ with meta-phosphoric acid. Samples were centrifuged at $600 \mathrm{~g}$ for $20 \mathrm{~min}$. The supernatant $(0.2 \mathrm{ml})$ and $5 \%$ DTT $(0.2 \mathrm{ml})$ were mixed and diluted to $2 \mathrm{ml}$ with water.

The determination of vitamin C, using HPLC method, was performed as described previously 10 (Gliszczyńska-Świgło et al. 2003). Waters 600 high performance liquid chromatograph 11 (Waters, Millford, Ma, USA) equipped with LiChrospher $\mathrm{C}_{18}(3.9$ x $250 \mathrm{~mm}, 5 \mu \mathrm{m}$, Merck, 12 Darmstadt, Germany) fitted with the same guard column was applied. A gradient of mobile 13 phase consisting of methanol (solvent A) and 5 mM KH${ }_{2} \mathrm{PO}_{4} \mathrm{pH} 2.65$ (solvent B) was used 14 according to the following gradient: linear increment starting with 5\% A to $22 \% \mathrm{~A}$ in 6 min 15 and the return to the initial conditions within next 9 min with the flow rate $0.8 \mathrm{ml} / \mathrm{min}$. The 16 eluate was detected using a Waters 996 photodiode-array detector set at $245 \mathrm{~nm}$. Vitamin C 17 was identified by comparing its UV spectrum and retention time with that of standard. 18 Quantification of vitamin C was done using the external standard method.

\section{Extraction and determination of carotenoids and tocopherols}

21 Carotenoids and tocopherols were extracted according to the method described in Polish 22 Norm (PN-90/A-75101/12) with one minor modification: n-hexane was used instead of 23 acetone and $\mathrm{n}$-hexane. Briefly, $1.000 \mathrm{~g}$ of dry material was extracted with $50 \mathrm{ml}$ portion of $\mathrm{n}$ 24 hexane until the resulting extract was colourless. The fractions were combined and, if 25 necessary, dried using anhydrous $\mathrm{Na}_{2} \mathrm{SO}_{4}$. For simultaneous HPLC analysis of $\beta$-carotene, 26 lutein, $\alpha$ - and $\gamma$-tocopherols, n-hexane extracts were evaporated in vacuum at $30^{\circ} \mathrm{C}$ to the 27 dryness and dissolved in $2 \mathrm{ml}$ of tetrahydrofuran. HPLC analyses were performed at room 28 temperature on Waters 600 high-performance liquid chromatograph (Waters, Millford, Ma, 29 USA) equipped with Lichrospher $\mathrm{C}_{18}$ column $(3.9$ × $250 \mathrm{~mm}, 5 \mu \mathrm{m}$, Merck, Darmstadt, 30 Germany) fitted with the same guard column. The mobile phase published by Kurilich et al. 31 (1999) was a combination of acetonitrile/methanol/tetrahydrofuran at 52:40:8 (v/v/v). Flow 32 rate was $1.5 \mathrm{ml} / \mathrm{min}$ to $7 \mathrm{~min}$ and then $2 \mathrm{ml} / \mathrm{min}$ to $20 \mathrm{~min}$. $\beta$-Carotene and lutein were 33 detected using a Waters 996 photodiode-array detector set at $450 \mathrm{~nm}$. For determination of $\alpha$ - 
1 and $\gamma$-tocopherols, a Waters 474 scanning fluorescence detector set at emission wavelength of $2325 \mathrm{~nm}$ with an excitation at $295 \mathrm{~nm}$ was used. Emission slit width was $10 \mathrm{~nm}$, fluorometer 3 gain 100, and attenuation 1. Carotenoids and tocopherols were identified by comparing their 4 retention times with those of corresponding standards and by the spiking of samples with 5 appropriate standard. Additionally, photodiode-array detector was used to identify the 6 compounds on the basis of their absorption spectra. Quantification of carotenoids and 7 tocopherols was done using the external standard method. The content of carotenoids was 8 expressed as milligram $\beta$-carotene equivalents per $100 \mathrm{~g}$ of dry and fresh weight.

\section{Extraction and determination of glucosinolates}

11 Glucosinolates were analyzed by HPLC following enzymatic desulphatation according to the 12 Official Journal of European Communities (1990) as described earlier by Ciska et al. (2000). 13 Individual glucosinolates were identified by comparing the retention times with those of 14 standards or on the basis of available literature data for glucoraphanin (Kushad et al. 1999). 15 Quantification of glucosinolates was based on the internal standard (glucotropaeolin) and 16 relevant relative response factors (Official Journal of European Communities 1990).

\section{Determination of antioxidant capacity of broccoli extracts}

19 The Trolox Equivalent Antioxidant Capacities (TEAC) of different broccoli extracts 20 (containing vitamin $\mathrm{C}$, polyphenols and carotenoids together with tocopherols) to scavenge $21 \mathrm{ABTS}^{\circ+}$ radical cation were determined by the method of Re et al. (1999). Briefly, ABTS was 22 dissolved in water. $\mathrm{ABTS}^{\circ+}$ was generated by the reaction of ABTS stock solution with 23 potassium persulfate (final concentration of ABTS and potassium persulfate was $7 \mathrm{mM}$ and $242.45 \mathrm{mM}$, respectively). The mixture was allowed to stand in the dark at room temperature for $2512-16 \mathrm{~h}$ before use. For the study of extracts, the $\mathrm{ABTS}^{\circ+}$ solution was diluted with methanol 26 to an absorbance of about 0.8 at $734 \mathrm{~nm}$. Extracts and Trolox ${ }^{\circledR}$ were added as $1 \%(\mathrm{v} / \mathrm{v})$ 27 solutions of 100 times concentrated stock solutions to give the final concentrations required. 28 For each experiment, solvent blank was run. The decrease in absorbance caused by extract, 29 measured at $6 \mathrm{~min}$, reflects the $\mathrm{ABTS}^{\bullet+}$ radical cation scavenging capacity and was plotted 30 against the concentration of the broccoli in extract. The TEAC value (in mmol Trolox/100 $\mathrm{g}$ 31 of dry and fresh weight) represents the ratio of the slope of the linear plot for scavenging of $32 \mathrm{ABTS}^{\bullet+}$ radical cation by the extract to the slope of the plot for $\mathrm{ABTS}^{\bullet+}$ radical cation 33 scavenging by Trolox ${ }^{\circledR}$, used as an antioxidant standard. 
$2 \mathrm{DPPH}^{*}$ radical scavenging activities of the same extracts were determined using a modified 3 method of Brand-Williams et al. (1995) as described by Kim et al. (2002). Briefly, $100 \mu \mathrm{M}$ $4 \mathrm{DPPH}^{\circ}$ was dissolved in $80 \%$ aqueous methanol. The broccoli extracts $(0.03 \mathrm{ml}$ of different concentrations) were added to $0.87 \mathrm{ml}$ of $\mathrm{DPPH}^{\bullet}$ solution to give the final concentration required. The reaction mixtures were incubated in the dark at room temperature for $30 \mathrm{~min}$,

\section{Results and discussion}

22 Distribution of glucosinolates, polyphenols, vitamin C, carotenoids and tocopherols in fresh and processed broccoli.

Table I lists 8 aliphatic, 4 indole and 1 aralkyl glucosinolates identified in fresh, water-cooked and steamed broccoli The results of quantitative analysis show the differences in the content of predominant and total glucosinolates present in fresh, steamed and water-cooked broccoli. The predominant glucosinolates in fresh, water-cooked and steamed broccoli are glucoraphanin, glucobrassicin, neoglucobrassicin and glucoiberin. Glucoraphanin and glucobrassicin contents in fresh broccoli determined in this study are similar to those previously reported by Kushad et al. (1999).

\section{Table I}

The main glucosinolate in broccoli is glucoraphanin, frequently making up greater than $50 \%$ of the total glucosinolates. In this study, glucoraphanin constitutes about $60 \%$ of total 
1 glucosinolate content in fresh as well as in processed broccoli. Enzyme or acid hydrolysis of

2 glucoraphanin yields sulphoraphane (4-methylsulphinylbutyl isothiocyanate), which has been

3 shown to reduce the incidence of a number of tumors in various experimental models, both in

4 vivo in animals and in vitro in cell cultures due to induction of quinone reductase and 5 glutathione-S-transferase - phase II detoxification enzymes (Zhang et al. 1992). The

6 contributions of glucoiberin, glucobrassicin and neoglucobrassicin to the total content of 7 glucosinolates are 9\%,11\% and 10\%, respectively. Hydrolysis product of glucobrassicin 8 (indole-3-carbinol), similarly to sulphoraphane, have been associated with upregulation of 9 phase II detoxification enzymes and also with upregulation of cytochrome P-450 isoenzymes 10 (like for instance CYP 1A) (Staack et al. 1998).

The results of the present study indicate the increase in the main and total glucosinolate 13 contents in broccoli upon steam-cooking (Table I; Figure 1). The content of aliphatic 14 glucosinolates (glucoiberin and glucoraphanin) and indole glucosinolates (glucobrassicin and 15 neoglucobrassicin) increased 1.1-fold and 1.4-1.6-fold as compared to fresh broccoli, 16 respectively. Total glucosinolate content increased 1.2-fold. Conaway et al. (2000) and 17 Vallejo et al. (2002) did not find any significant influence of steaming on glucosinolate 18 content in broccoli steamed for 15 and 3.5 minutes, respectively. Although, $10 \mathrm{~min}$ of 19 steaming, used in our study, is in the range of literature data, our results are different because 20 even small difference in cooking time may influence the results as it was shown in other 21 studies (Ciska et al., 1994, 2001). It can not be excluded that just 10 minutes might be the 22 threshold time that causes the increase in the glucosinolate content upon steaming. The 23 steaming of broccoli for 3.5 minutes might be too short to observe significant increase of the 24 glucosinolates in the extracts from steamed broccoli. On the other hand, 15 minutes steaming 25 might be too long and therefore, after initial increase, some losses of glucosinolates may 26 occur. Moreover, the differences in our and literature data might be a result of difference in 27 broccoli cultivar.

\section{Figure 1}

30 According to Ciska et al. (2001) the increase in the content of glucosinolates may result from 31 a deep disintegration of plant tissue upon heat treatment because part of glucosinolates in 32 plant cells can be bound to the cell walls and released only after a deep disintegration of cell 33 structures. Such an assumption can be supported by the reports concerning the presence of 34 myrosinase, a native enzyme catalyzing the glucosinolates hydrolysis, in the cell wall 
1 (Bjergegaard et al. 1995). The presence of the enzyme-substrate system in the cell wall is also 2 a prerequisite for releasing of the degradation products only as a result of breaking the 3 structure of the cell wall. A hypothesis assuming the possibility of glucosinolates binding to 4 the cell walls, as in the case of other low-molecular compounds e.g. saccharides, glycosides, 5 and inositol phosphates, would be in line with a theory assuming the glucosinolates presence in vacuole being their main reservoir in the cell (Lüthy et al. 1984).

In contrast, cooking of broccoli in water for 5 min leads to considerable loss of glucosinolates (Figure 1). The neoglucobrassicin is the most affected by the water-cooking; its concentration decreased by $63 \%$. The loss of other glucosinolates is $43 \%$ (glucoiberin), and $47 \%$ (glucoraphanin and glucobrassicin); the total glucosinolate content decreased by $46 \%$. The observed losses of glucosinolates are most likely due to their leaching into the cooking-water.

Similar losses of glucosinolates and/or hydrolysis products upon various cooking methods were reported in other studies. Vallejo et al. (2002) reported even higher loss of glucosinolates in water- and microwave-cooked broccoli $(74 \%)$ than that observed in our study. Similar effect was reported by Rosa et al. (1993) with cooked cabbage. According to Howard et al. (1997), microwave cooking of broccoli at full power for 8 minutes, causes considerable loss of sulforaphane. The decrease in the content of glucosinolates during cooking of Brussels sprouts and white cabbage (up to 20 minutes), as a result of thermal and initially also enzymatic degradation of glucosinolates, was reported by Ciska et al. (1994, 2001). The decrease in the content of glucosinolates in these vegetables was different for individual compounds and it was dependent on the cooking time. Analysis of the cooking water showed that the losses of glucosinolates were partly due to their leaching into the cooking water (Ciska et al. 2001).

The results presented in Table II show the influence of domestic processing on the content of total polyphenols, flavonoids, phenolic acids, vitamin $\mathrm{C}$ and $\mathrm{E}$, as well as carotenoids in broccoli.

\section{Table II}

Fresh broccoli contains $681.2 \mathrm{mg} / 100 \mathrm{~g}$ d.w. (84.5 mg/100 g f.w.) of vitamin C. The cooking of broccoli in water considerably affects the content of vitamin $\mathrm{C}$, yielding losses of $23 \%$. No significant effect of steam-cooking on vitamin C content was observed (Figure 2). Similar 
1 effect of steaming on vitamin C content in broccoli was observed by Vallejo et al. (2002). In 2 the study of Zhang et al. (2004) the loss of vitamin C upon water-cooking for 5 min was 3 approximately 2-fold higher than observed in our study. According to literature data, the 4 content of vitamin $\mathrm{C}$ in edible parts of fresh broccoli, depending on variety, may vary from 543.2 to $146.4 \mathrm{mg} / 100 \mathrm{~g}$ of fresh weight (Vallejo et al. 2003). Based on available biochemical, 6 clinical, and epidemiological studies, the current recommended daily acceptance (RDA) for 7

\section{Figure 2}

12 The content of total polyphenols in fresh broccoli $886.3 \mathrm{mg} / 100 \mathrm{~g}$ d.w. (109.9 mg/100 g f.w.), 13 determined in this study, is in agreement with the results previously reported (from 34.5 to $14128 \mathrm{mg}$ gallic acid/100 g f.w.) (Leja et al. 2001, Proteggente et al. 2002, Zhang et al. 2004). It 15 was found that cooking of broccoli in water affects the content of total polyphenols, yielding 16 loss of $13 \%$ (Figure 2). Zhang et al. (2004) reported that total polyphenols were retained in $28 \%$ in the cooked florets.

Acid hydrolysis of the broccoli phenolic extracts yields kaempferol as the main compound, followed by quercetin and isorhamnetin. After alkaline hydrolysis caffeic, $p$-coumaric, sinapic as well as ferulic acids were found to be the main acids present in the broccoli phenolic extracts (results not shown). The losses of flavonoids and phenolic acids in water-cooked broccoli were $72 \%$ and $52 \%$, respectively as compared to fresh broccoli (Figure 2). These results show that processing of broccoli by cooking in water has stronger effect on the content of flavonoids than on phenolic acids. Similar losses, in case of flavonoids, were reported by Price et al. (1998). They found that during cooking of broccoli in water for 15 minutes, 14$28 \%$ of individual flavonol glycosides were retained in the cooked tissue, the remainder being largely leached into the cooking water.

30 The analysis of water, in which broccoli was cooked, confirmed that the losses of both vitamin $\mathrm{C}$ and polyphenols are mainly due to their leaching into the cooking water.

33 In contrast, steaming of broccoli leads to the increase in the content of total polyphenols (1.6fold), flavonoids (1.5-fold) and phenolic acids (1.3-fold) in comparison to fresh broccoli 
1 (Figure 2). Similar effect of steaming on the level of polyphenols in broccoli and green beans 2 was observed by Turkmen et al. (2005). It was also reported that heat treatment causes the 3 increase of free flavonols in tomato-based products (Stewart et al. 2000). The apparent 4 increase in polyphenols is most likely due to disruption of complexes between polyphenols and e.g. proteins resulting in better availability of these compounds to extraction from steamed broccoli as compared to fresh one.

$\beta$-Carotene and lutein contents in fresh broccoli (Table I) are in the range of literature data (from 0.37 to $2.42 \mathrm{mg} / 100 \mathrm{f} . \mathrm{w}$. and from 0.80 to $2.83 \mathrm{mg} / 100 \mathrm{~g}$ f.w., respectively) (Heinonen et al. 1989, Khachik et al. 1992, Lessin et al. 1997, Müller 1997, Kurilich et a. 1999, Zhang et 11 al. 2004). The contents of tocopherols are similar to those previously published by Burns et al. 12 (2003) but they are much lower than those reported by Kurilich et al. (1999) and Lessin et al. 13 (1997). In contrast to vitamin $C$ and polyphenols, both cooking methods (boiling in water and 14 steaming) leads to the increase in $\beta$-carotene and lutein contents (Figure 3 ). The increase in $\beta$ carotene was 1.9-fold and 2.3-fold in steamed and water-cooked broccoli, respectively; for lutein -4.1 and 6-fold, respectively. From the results presented (Figure 3) it follows that $\alpha$ tocopherol content increased 1.2-fold and 1.7-fold upon steaming and cooking of broccoli in water, respectively. Similar effect was found for $\gamma$-tocopherol (1.4-fold and 1.7-fold, respectively). Carotenoids and tocopherols have not been detected in the cooking water.

\section{Figure 3}

Since tocopherols are largely resistant to heating up to $200^{\circ} \mathrm{C}$, in the absence of oxygen and oxidizing lipids (Friedrich 1998), and it was also reported that little or no degradation of $\beta$ carotene occurs during thermal processing (Chandler et al. 1988, Khachik et al. 1992), the increase in the content of tocopherols and carotenoids observed in our study is most likely a result of better availability of these compounds for extraction. For carotenoids, the increase in their concentration in processed broccoli is most likely a result of improved extraction in part due to disruption of carotenoprotein complexes and inactivation of carotene oxidizing enzymes (Lessin et al. 1997). The higher content of carotenoids and tocopherols in watercooked than in steamed broccoli seem to support the conclusion that the increase in the content of these compounds is related to the improved extraction; availability of extracted 
1 steamed broccoli. In the study of Lessin et al. (1997), where water-cooked broccoli was 2 compared with the fresh one, about 1.2-fold increase in the $\beta$-carotene content was observed. 3 Similar effect of heat-based processing on the content of lycopene in tomatoes was observed 4 by Re et al. (2002). It was also reported that carotene content increases during blanching, lye 5 peeling and pureeing of sweet potatoes. It was also attributed to an enhanced extraction of 6 carotenoids from heat-treated samples (Chandler et al. 1988).

\section{Antioxidant capacities of broccoli extracts}

9 The TEAC and DPPH antioxidant activities of fresh, steamed and water-cooked broccoli (Table III) generally reflect the results of quantification of polyphenols, carotenoids, vitamin $11 \mathrm{C}$ and $\mathrm{E}$ in broccoli. The antioxidant activities of water-cooked broccoli decreased by $6 \%$ for polyphenol extract and $26 \%$ for vitamin C extract in the TEAC assay. In the DPPH assay, 13 antioxidant activities decreased by $29 \%$ and $16 \%$ for polyphenols and vitamin $\mathrm{C}$ extracts, 14 respectively. For steamed broccoli the increase in the antioxidant activities of polyphenol and 15 vitamin $\mathrm{C}$ extracts was observed as compared to fresh broccoli: 1.3-fold for both extracts in the TEAC and DPPH assays (Figure 4).

\section{Table III}

\section{Figure 4}

19 The antioxidant activities of carotenoid and tocopherol extracts obtained from steamed and 20 water-cooked broccoli increased 2.2-fold and 2.9-fold, respectively as compared to that of 21 fresh broccoli (Figure 5). The effects of domestic processing on the TEAC values support the 22 conclusion on an increased availability of carotenoids and tocopherols for extraction upon steam- and water-cooking. In DPPH assay, no significant activities of carotenoids and tocopherol extracts were observed. Antioxidant activities of glucosinolates in broccoli extracts were not determined because they are not effective free radical scavengers (Plumb et al. 1996, Williamson et al. 1998).

\section{Figure 5}

\section{Conclusions}

29 The results indicate that steam-cooking of broccoli results in an increase in the content of 30 flavonoids and phenolic acids, as well as the main glucosinolates and their total content as 31 compared to fresh broccoli, whereas cooking in water has opposite effect. Steam-cooking of 32 broccoli has no influence on vitamin $\mathrm{C}$ content, whereas cooking in water significantly lowers 33 the content of this vitamin. Both water- and steam-cooking of broccoli results in an increase 
1 in $\beta$-carotene, lutein and vitamin $\mathrm{E}$ as compared to fresh one. The increase in the content of 2 polyphenols, carotenoids, glucosinolates and vitamin $\mathrm{E}$ is related to their enhanced 3 availability for the extraction, whereas the observed losses of the compounds are mainly due 4 to their leaching into the cooking-water. The changes in the content of health-promoting 5 compounds of broccoli upon domestic processing are generally reflected by the changes in the 6 antioxidant activities of broccoli extracts. 7

8 Moreover, the results of the present study and the literature data show that the concentration 9 and availability of different health-promoting compounds present in broccoli are dependent 10 on the matrix, in which they are present. Furthermore, steam-cooking of broccoli may be 11 considered a "friendly" process, preserving health-promoting compounds that are important 12 for preventing adverse health effects and maintaining food quality. 13

\section{Acknowledgements}

The grant from State Committee for Scientific Research (Poland), PBZ-KBN16 094/P06/2003, 2004-2006, is gratefully acknowledged. 


\section{References}

2 Bjergegaard, C., Li, P.W., Michaelsen, S., Møller, P., Otte J., Sørensen, H., 1994,

Glucosinolates and their transformation products - compounds with a broad biological activity. Proceedings of the International European Food Tox IV Conference, Bioactive substances in foods of plant origin. (Olsztyn: Center for Agrotechnology and Veterinary Science), pp. 36-39.

Bjergegaard, C., Sorensen, H., 1995, Characterisation of proteins, including myrosinases, associated to rapeseed dietary fibres, compared to proteins in pea dietary fibres. Polish Journal of Food and Nutrition Sciences, 4/45, 47-57.

Block, G., Patterson, B., Sauber, A., 1992, Fruit, vegetables and cancer prevention: a review of epidemiological evidence. Nutrition and Cancer, 18, 1-29.

Brand-Williams, W., Cuvelier, M. E., Berset, C., 1995, Use of a free radical method to evaluate antioxidant activity. Lebensmittel-Wissenschaft und Technologie, 28, 25-30.

Burns, J., Fraser, P. D., Bramley, P. M., 2003, Identification and quantification of carotenoids, tocopherols and chlorophylls in commanly consumed fruits and vegetables. Phytochemistry, 62, 939-947.

Chandler, L. A., Schwartz, S. J., 1988, Isomerization and losses of trans- $\beta$-carotene in sweet potatoes as affected by processing treatments. Journal of Agricultural and Food Chemistry, 36, 129-133.

Ciska, E., Waszczuk, K., Kozłowska, H., 1994, Changes in glucosinolate content in selected cruciferous vegetables during cooking. Proceedings of the International European Food Tox IV Conference, Bioactive substances in foods of plant origin. (Olsztyn: Center for Agrotechnology and Veterinary Science), pp. 36-39.

Ciska, E., Martyniak-Przybyszewska, B., Kozlowska, H., 2000, Content of glucosinolates in cruciferous vegetables grown at the same site for two years under different climatic conditions. Journal of Agricultural and Food Chemistry, 48, 2862-2867.

Ciska, E., Kozłowska, H., 2001, The effect of cooking on the glucosinolates content in white cabbage. European Food Research and Technology, 212, 582-587.

Conaway, C. C., Getahun, S. M., Liebes, L. L., Pusateri, D. J., Topham, D. K. W., BoteroOmary, D., Chung, F-L., 2000, Disposition of glucosinolates and sulforaphane in humans after ingestion of steamed and fresh broccoli. Nutrition and Cancer, 38, 168-178. 
1 Crozier, A., Lean, M. E. J., McDonald, M. S., Black, C., 1997, Quantitative analysis of the flavonoid content of commercial tomatoes, onions, lettuce, and celery. Journal of Agricultural and Food Chemistry, 45, 590-595.

Duell, P. B., 1996, Prevention of atherosclerosis with dietary antioxidants: fact or fiction? Journal of Nutrition, 126, 1067s-1071s.

EEC (19990) Official Journal of the European Communities, L 170: 33, 3, July 1990.

Faulkner, K., Mithen, R., Williamson, G., 1998, Selective increase of the potential anticarcinogen 4-methylsulphinylbutyl glucosinolate in broccoli. Carcinogenesis, 19, 605609.

Friedrich W., 1988, Vitamin E. In: Vitamins. Berlin, New York: Walter de Gruyter. pp. 219283.

Gliszczyńska-Świgło, A., Tyrakowska, B., 2003, Quality of commercial apple juices evaluated on the basis of the polyphenol content and the TEAC antioxidant activity. Journal of Food Science, 68, 1844-1849.

Heinonen, M. I., Ollilainen, V., Linkola, E. K., Varo, P. T., Koivistoinen, P. E., 1989, Carotenoids in Finnish foods: vegetables, fruits, and berries. Journal of Agricultural and Food Chemistry, 37, 655-659.

Howard, L. A., Jeffery, E. H., Wallig, M. A., Klein, B. P., 1997, Retention of phytochemicals in fresh and processed broccoli. Journal of Food Science, 62, 1098-1104.

Janero, D. R., 1995, Ischemic heart disease and antioxidants: mechanistic aspects of oxidative injury and its prevention. Critical Reviews in Food Science and Nutrition, 35, 65-81.

Kaur, C., Kapoor, H. C., 2001, Antioxidants in fruits and vegetables - the millennium's health. International Journal of Food Science and Technology, 36, 703-725.

Khachik, F., Goli, M. B., Beecher, G. R., Holden, J., Lusby, W. R., Tenorio, M. D., Barrera, M. R., 1992, Effect of food preparation on qualitative and quantitative distribution of major carotenoids constituents of tomatoes and several green vegetables. Journal of Agricultural and Food Chemistry, 40, 390-398.

Kim, D-O., Lee, K. W., Lee, H. J., Lee, C. Y., 2002, Vitamin C equivalent antioxidant capacity (VCEAC) of phenolic phytochemicals. Journal of Agricultural and Food Chemistry, 50, 3713-3717.

Kohlmeier, L., Su, L., 1997, Cruciferous vegetable consumption and colorectal cancer risk: meta-analysis of the epidemiological evidence. The FASEB Journal, 11, 369.

Kritchevsky, S. B., 1999, $\beta$-Carotene, carotenoids and the prevention of coronary heart disease. Journal of Nutrition, 129, 5-8. 
1 Kurilich, A. C., Tsau, G. J., Brown, A., Howard, L., Klein, B. P., Jeffery, E. H., Kushad, M., Wallig, M. A., Juvik, J. A., 1999, Carotene. Tocopherol. And ascorbate contents in subspecies of Brassica oleracea. Journal of Agricultural and Food Chemistry, 47, 15761581.

Kushad, M. M., Brown, A. F., Kurilich, A. C., Juvik, J. A., Klein, B. P., Wallig, M. A., Jeffery, E. H., 1999, Variation of glucosinolates in vegetable crops of Brassica oleracea. Journal of Agricultural and Food Chemistry, 47, 1541-1548.

Landrum, J. T., Bone, R. A., 2001, Lutein, zeaxanthin and the macular pigment. Archives of Biochemistry and Biophysics, 385, 28-40.

Leja, M., Mareczek, A., Starzyńska, A., Rożek, S., 2001, Antioxidant ability of broccoli flower buds during short-term storage. Food Chemistry, 72, 219-222.

Lessin, W. J., Catigani, G. L., Schwartz, S. J., 1997, Quantification of cis-trans isomers of provitamin A carotenoids in fresh and processed fruits and vegetables. Journal of Agricultural and Food Chemistry, 45, 3728-3732.

Lüthy, B., Matile, P. H., 1984, The mustard oil bomb: rectified analysis of the subcellular organization of the myrosinase system. Biochemie und Physiologie der Pflanzen, 179, 512.

Middleton, E., Kandaswami, C., 1993, The impact of plant flavonoids on mammalian biology: implications for immunity, inflammation and cancer. The Flavonoids: Advances in Research since 1986, edited by J. B. Harborne (London: Chapman and Hall), p 619652.

Murillo, G., Mehta, R. G., 2001, Cruciferous vegetables and cancer prevention. Nutrition and Cancer, 41, 17-28.

Müller, H., 1997, Determination of the carotenoid content in selected vegetables and fruits by HPLC and photodiode array detection. Zeitschrift fur Lebensmittel-Untersuchung und Forschung A, 204, 88-94.

Naidu, K. A., 2003, Vitamin C in human health and disease is still a mystery? An overview. Journal of Nutrition, 2, 1-16.

Plumb, G. W., Lambert, N., Chambers, S. J., Wanigatunga, S., Heaney, R. K., Plumb, J. A., Aruoma, O. I., Halliwell, B., Miller, N. J., Williamson, G., 1996, Are whole extracts and purified glucosinolates from cruciferous vegetables antioxidants? Food Chemistry, 25, 7586.

Preobrazhenskaya, M.N., Bukhman, V.M., Karolev, A.M., Efimov, S.A., 1993, Ascorbigen and other indole-derived compounds from Brassica vegetables and their analogs as 
anticarcinogenic and immunomodulating agents. Pharmacology \&. Therapeutics 60, 301313.

Price, K. R, Casuscelli, F., Colquhoun, I. J., Rhodes, M. J. C., 1998, Composition and content of flavonol glycosides in broccoli florets (Brassica oleracea) and their fate during cooking. Journal of the Science of Food and Agriculture, 77, 468-472.

Proteggente, A. R., Pannala, A. S., Paganga, G., van Buren, L., Wagner, E., Wiseman, S., van de Put, F., Dacombe, C., Rice-Evans, C., 2002, The antioxidant activity of regularly consumed fruit and vegetables reflects their phenolic and vitamin $\mathrm{C}$ composition. Free Radicals Research, 36, 217-233.

Re, R., Pellergini, N., Proteggente, A., Pannala, A. S., Yang, M., Rice-Evans, C., 1999, Antioxidant activity applying an improved ABTS radical cation decolorization assay. Free Radical Biology and Medicine, 26, 1231-1231.

Re, R., Bramley, P. M., Rice-Evans, C., 2002, Effects of food processing on flavonoids and lycopene status in a mediterranean tomato variety. Free Radical Research, 36, 803-810.

Rosa, E. A. S., Heaney, R. K., 1993, The effect of cooking and processing on the glukosinolate content: studies on four varieties of Portuguese cabbage and hybrid white cabbage. Journal of the Science of Food and Agriculture, 62, 259-265.

Samman, S., Lyons Wall, P. M., Cook, N. C., 1998, Flavonoids and coronary heart disease:dietary perspectives. Flavonoids in health and disease, edited by C. A. RiceEvans, L. Parker (New York: Marcel Decker inc), p 469-481.

Singleton, V. L., Rossi, J. A., 1965, Colorimetry of total phenolics with phosphomolybdicphosphotungstic acid reagents. American Journal of Entology Vitic, 16, 144-158.

Staack, R., Kingston, S., Wallig, M. A., Jeffery, E. H., 1998, A comparison of the individual and collective effects of four glucosinolate breakdown products from Brussels sprouts on induction of detoxification enzymes. Toxicology and Applied Pharmacology, 149, 17-23.

Stewart, A. J., Bozonnet, S., Mullen, W., Jenkins, G. J., Michael, E. J., Crozier, A., 2000, Occurrence of flavonols in tomatoes and tomatoe-based products. Journal of Agricultural and Food Chemistry, 48, 2663-2669.

Turkmen, N., Sari, F., Velioglu, S., 2005, The effect of cooking methods on total phenolics and antioxidant activity of selected green vegetables. Food Chemistry, 93, 713-718.

Vallejo, F., Tomas-Barberan, F. A., Garcia-Viguera, C., 2004, Characterisation of flavonols in broccoli (Brassica oleracea L. var. italica) by liquid chromatography-UV diode-array detection-electrospray ionisation mass spectrometry. Journal of Chromatography A, 1054, 181-193. 
1 Vallejo, F., Tomas-Barberan, F. A., Garcia-Viguera, C., 2003, Potential bioactive compounds 2 in health promotion from broccoli cultivars grown in Spain. Journal of the Science of 3 Food and Agriculture, 82, 1293-1297.

4 Vallejo, F., Tomas-Barberan, F. A., Garcia-Viguera, C., 2002, Glucosinolates and vitamin C 5 content in edible parts of broccoli florets after domestic cooking. European Food Research 6

7 Williamson, G., Dupont, M. S., Wanigatunga, S., Heaney, R. K., Musk, S. R. R., Fenwick, G. 8 R., Rhodes, M. J. C., 1997, Induction of glutathione-S-transferase activity in hepG2 cells 9 by extracts from fruits and vegetables. Food Chemistry, 60, 157-160.

10 Williamson, G., Faulkner, K, Plumb G. W., 1998, Glucosinolates and phenolics as 11 antioxidants from plant foods. European Journal of Cancer Prevention, 7, 17-21.

12 Zhang, D., Hamauzu, Y., 2004, Phenolics, ascorbic acid, carotenoids and antioxidant activity 13 of broccoli and their changes during conventional and microwave cooking. Food 14 Chemistry, 88, 503-509.

15 Zhang, Y., Talalay, P., Cho, C-G., Posner, G. H., 1992, A major inducer of anticarcinogenic 16 protective enzymes from broccoli: isolation and elucidation of structure; Proceedings of 17 the National Academy of Science USA, 89, 2399-2403. 18 19 20 21 22 23 24 




Figure 1. The changes in the content of total and the main glucosinolates (referred to dry weight) in broccoli upon water- and steam-cooking. 


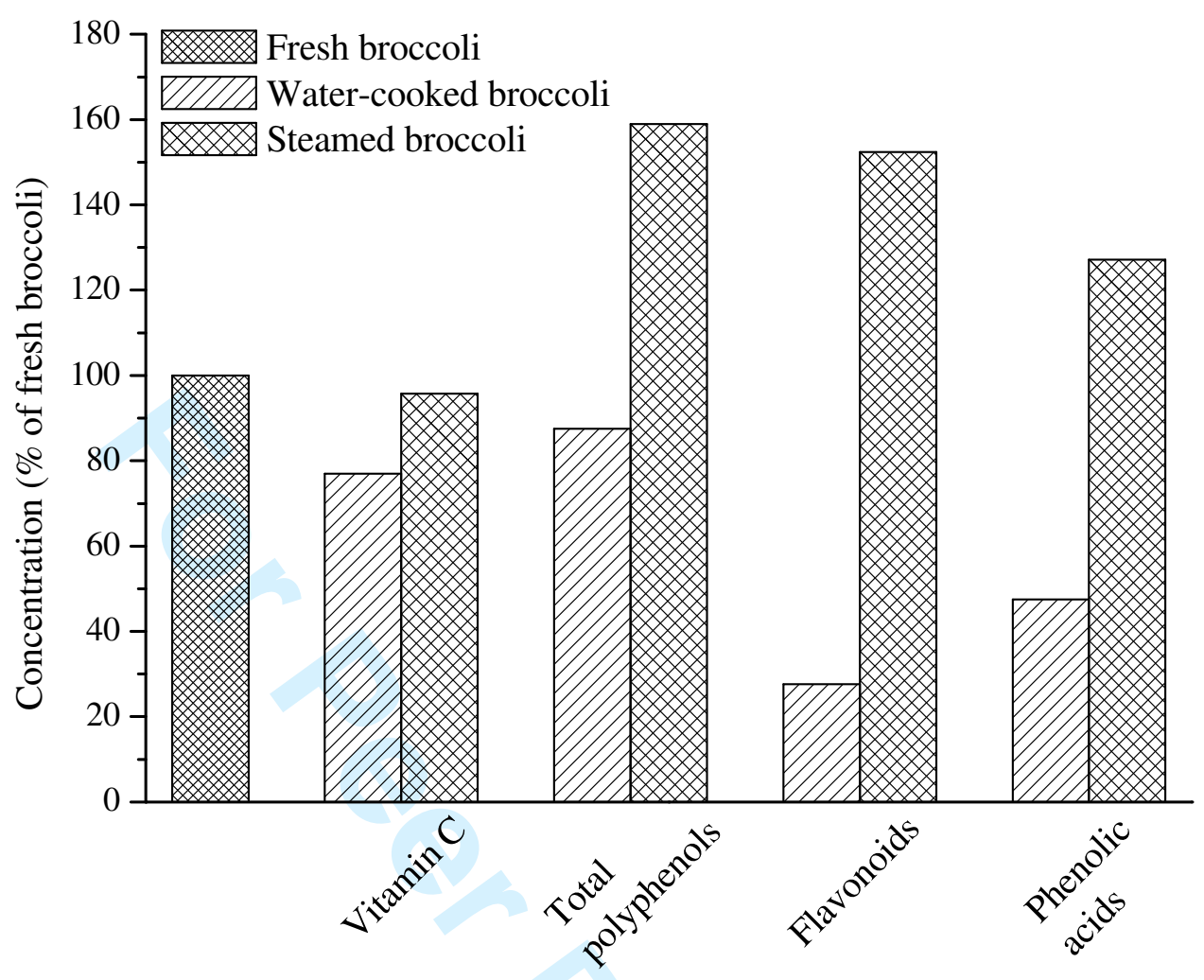

Figure 2. The changes in the content of vitamin C, total polyphenols, flavonoids and phenolic 3 acids (referred to dry weight) in broccoli upon water- and steam-cooking. 




2 Figure 3. The changes in the content of $\beta$-carotene, lutein, $\alpha$ - and $\gamma$-tocopherols (referred to 3 dry weight) in broccoli upon water- and steam-cooking. 

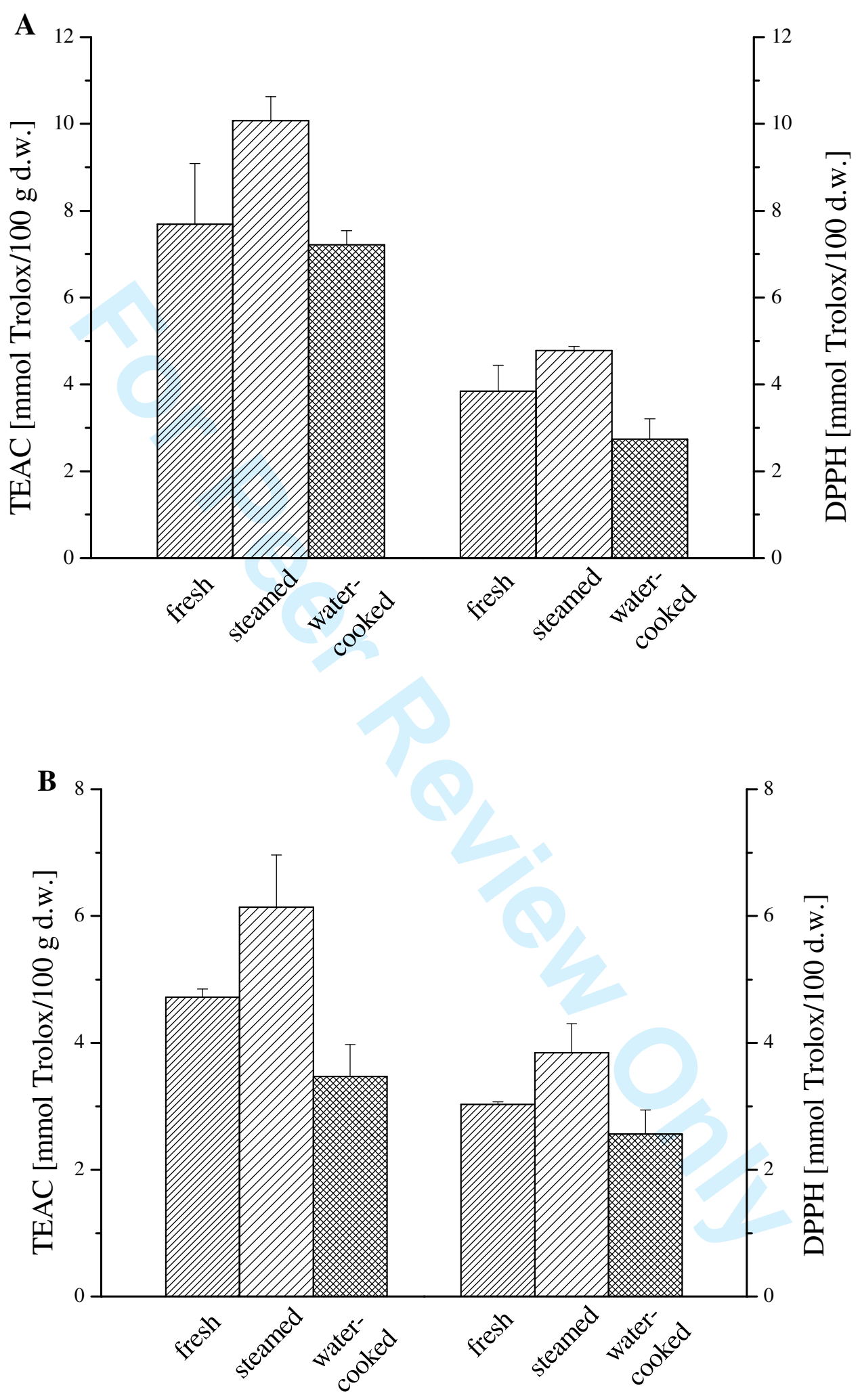

Figure 4. The changes in the TEAC and the DPPH values of (A) polyphenol extracts and 5

(B) vitamin $\mathrm{C}$ extracts from domestically processed broccoli. 


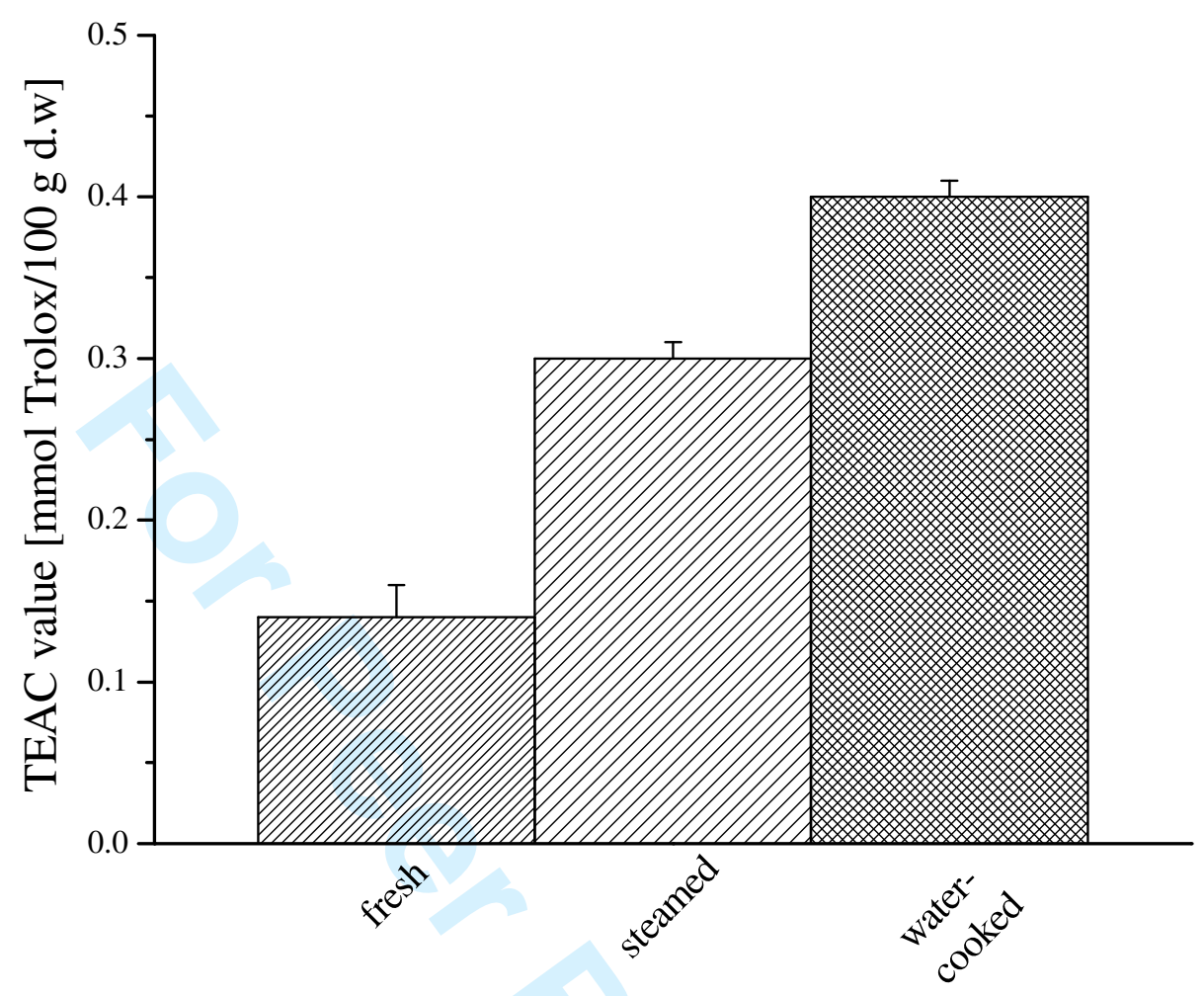

3 Figure 5. The changes in the TEAC value of carotenoid and tocopherol extracts from 4 domestically processed broccoli. 5 
1 Table I. Glucosinolate content ( $\mu \mathrm{mol} / \mathrm{g}$ dry weight) in fresh, steamed and water-cooked 2 broccoli.

3

\begin{tabular}{clccc}
\hline \multirow{2}{*}{ Compound } & \multicolumn{3}{c}{ Glucosinolate content } \\
\cline { 3 - 5 } & \multicolumn{1}{c}{ Gliphatics } & $\begin{array}{c}\text { Fresh } \\
\text { broccoli }\end{array}$ & $\begin{array}{c}\text { Steamed } \\
\text { broccoli }\end{array}$ & $\begin{array}{c}\text { Water- } \\
\text { cooked } \\
\text { broccoli }\end{array}$ \\
& Progoitrin & 1.43 & 1.58 & 0.81 \\
& Glucoraphanin & 0.18 & 0.19 & 0.14 \\
& Napoleiferin & 9.60 & 10.19 & 5.09 \\
& Glucoalyssin & 0.31 & 0.26 & 0.14 \\
& Gluconapin & 0.07 & 0.15 & 0.10 \\
& Glucoibervirin & Traces & Traces & Traces \\
& Glucoerucin & Traces & 0.05 & Traces \\
& Gluconasturtiin & Traces & Traces & Traces \\
\hline Aralkyl & 4-Hydroxyglucobrassicin & 0.63 & 0.76 & 0.05 \\
\hline Indoles & Glucobrassicin & 1.76 & 2.78 & 0.93 \\
& 4-Metoxyglucobrassicin & 0.36 & 0.48 & 0.30 \\
& Neoglucobrassicin & 1.60 & 2.21 & 0.59 \\
\hline Total & & 16.04 & 18.79 & 8.58 \\
\hline
\end{tabular}

Traces $=<0.05 \mu \mathrm{mol} / \mathrm{g}$ dry weight 
1 Table II. Distribution (mean $\pm \mathrm{SD}$ ) of compounds analysed in fresh and domestically-

2 processed broccoli $(\mathrm{mg} / 100 \mathrm{~g})$.

\begin{tabular}{|c|c|c|c|c|}
\hline Compounds & & Fresh & Steamed & Water-cooked \\
\hline \multirow{2}{*}{ Total polyphenols ${ }^{1}$} & dry weight & $886.3 \pm 104.3$ & $1409.1 \pm 31.1$ & $775.8 \pm 55.7$ \\
\hline & fresh weight* & $109.9 \pm 12.9$ & $167.3 \pm 3.7$ & $89.2 \pm 6.4$ \\
\hline \multirow[t]{2}{*}{ Flavonoids $^{2}$} & dry weight & $25.4 \pm 1.4$ & $38.7 \pm 0.8$ & $7.0 \pm 0.8$ \\
\hline & fresh weight & $3.15 \pm 0.17$ & $4.59 \pm 0.09$ & $0.81 \pm 0.10$ \\
\hline \multirow{2}{*}{ Phenolic acids $^{3}$} & dry weight & $328.1 \pm 25.9$ & $417.3 \pm 2.0$ & $155.9 \pm 20.0$ \\
\hline & fresh weight & $40.55 \pm 3.20$ & $50.05 \pm 0.91$ & $17.93 \pm 2.30$ \\
\hline \multirow[t]{2}{*}{ Vitamin C } & dry weight & $681.2 \pm 18.3^{\mathrm{a}}$ & $652.6 \pm 46.3^{\mathrm{a}}$ & $524.8 \pm 1.2$ \\
\hline & fresh weight & $84.5 \pm 2.3^{\mathrm{a}}$ & $77.7 \pm 5.5^{\mathrm{a}}$ & $60.3 \pm 0.1$ \\
\hline \multirow{2}{*}{$\beta$-Carotene } & dry weight & $10.50 \pm 0.54$ & $19.93 \pm 0.48$ & $24.61 \pm 0.48$ \\
\hline & fresh weight & $1.30 \pm 0.07$ & $2.37 \pm 0.04$ & $2.83 \pm 0.06$ \\
\hline \multirow[t]{2}{*}{ Lutein } & dry weight & $6.47 \pm 0.33$ & $26.60 \pm 1.60$ & $38.8 \pm 1.85$ \\
\hline & fresh weight & $0.80 \pm 0.04$ & $3.16 \pm 0.19$ & $4.46 \pm 0.21$ \\
\hline \multirow{2}{*}{$\alpha$-Tocopherol } & dry weight & $0.727 \pm 0.047$ & $0.895 \pm 0.012$ & $1.272 \pm 0.044$ \\
\hline & fresh weight & $0.090 \pm 0.006$ & $0.106 \pm 0.001$ & $0.146 \pm 0.005$ \\
\hline \multirow{2}{*}{$\gamma$-Tocopherol } & dry weight & $0.072 \pm 0.003$ & $0.104 \pm 0.003$ & $0.125 \pm 0.002$ \\
\hline & fresh weight & $0.009 \pm 0.000$ & $0.012 \pm 0.000$ & $0.014 \pm 0.000$ \\
\hline \multirow{2}{*}{ Vitamin $\mathrm{E}^{4}$} & dry weight & $0.798 \pm 0.049$ & $0.999 \pm 0.015$ & $1.397 \pm 0.046$ \\
\hline & fresh weight & $0.099 \pm 0.006$ & $0.119 \pm 0.002$ & $0.161 \pm 0.005$ \\
\hline
\end{tabular}

31 - measured using Folin-Ciocalteu method; 2 - determined by HPLC method after acid hydrolysis 4 and quantified as quercetin; 3 - determined by HPLC method after alkaline hydrolysis and quantified 5 as sinapic acid; 4 - calculated as the sum of $\alpha$ - and $\gamma$-tocopherols; a - not significantly different at $6 \mathrm{P}<0.05$

$7 *$ Due to the fact that literature data for polyphenol, flavonoid, vitamin $\mathrm{C}$ and $\mathrm{E}$, and carotenoid 8 contents in broccoli are mostly referred to fresh weight, Table II additionally contains the results 9 expressed in $\mathrm{mg} / 100 \mathrm{~g}$ fresh weight. 
1 Table III. Antioxidant activity (mmol Trolox/100 g) of polyphenol, vitamin C and

2 carotenoid/tocopherol extracts from fresh, water-cooked and steamed broccoli (mean $\pm \mathrm{SD}$ )

3

\begin{tabular}{lllcc}
\hline & & Fresh broccoli & Steamed broccoli & $\begin{array}{c}\text { Water-cooked } \\
\text { broccoli }\end{array}$ \\
\hline \multirow{2}{*}{ TEAC value } & \multicolumn{2}{c}{ Antioxidant activity of polyphenol extracts } & \\
\cline { 2 - 5 } & dry weight & $7.69 \pm 1.40$ & $10.07 \pm 0.56$ & $7.22 \pm 0.32$ \\
\hline \multirow{2}{*}{ fresh weight* } & $0.95 \pm 0.07$ & $1.20 \pm 0.07$ & $0.83 \pm 0.04$ \\
\cline { 2 - 5 } & dry weight & $3.84 \pm 0.60$ & $4.78 \pm 0.10$ & $2.74 \pm 0.47$ \\
\cline { 2 - 5 } & fresh weight & $0.47 \pm 0.07$ & $0.57 \pm 0.01$ & $0.31 \pm 0.05$ \\
\hline
\end{tabular}

Antioxidant activity of vitamin $C$ extracts

\begin{tabular}{lllll}
\hline \multirow{2}{*}{ TEAC value } & dry weight & $4.72 \pm 0.13$ & $6.14 \pm 0.82$ & $3.47 \pm 0.50$ \\
\cline { 2 - 5 } & fresh weight & $0.58 \pm 0.02$ & $0.73 \pm 0.10$ & $0.40 \pm 0.05$ \\
\hline \multirow{2}{*}{ DPPH value } & dry weight & $3.03 \pm 0.04$ & $3.84 \pm 0.46$ & $2.56 \pm 0.38$ \\
\cline { 2 - 5 } & fresh weight & $0.37 \pm 0.04$ & $0.46 \pm 0.05$ & $0.29 \pm 0.04$
\end{tabular}

Antioxidant activity of carotenoid and tocopherol extracts

\begin{tabular}{llccc}
\hline \multirow{2}{*}{ TEAC value } & dry weight & $0.138 \pm 0.016$ & $0.299 \pm 0.011$ & $0.403 \pm 0.007$ \\
\cline { 2 - 5 } & fresh weight & $0.017 \pm 0.002$ & $0.035 \pm 0.001$ & $0.046 \pm 0.001$ \\
\hline DPPH value & inactive & inactive & inactive
\end{tabular}

$4 *$ Due to the fact that literature data for the antioxidant activity of vegetables are mostly referred to

5 fresh weight, Table III additionally contains the results expressed in mmol Trolox/100 g fresh weight. 
2

3

4

\section{List of Figures:}

2 Figure 1. The changes in the content of total and the main glucosinolates (referred to dry

3 weight) in broccoli upon water- and steam-cooking.

4 Figure 2. The changes in the content of vitamin C, total polyphenols, flavonoids and phenolic 5 acids (referred to dry weight) in broccoli upon water- and steam-cooking.

6 Figure 3. The changes in the content of $\beta$-carotene, lutein, $\alpha$ - and $\gamma$-tocopherols (referred to 7 dry weight) in broccoli upon water- and steam-cooking.

8 Figure 4. The changes in the TEAC and the DPPH values of (A) polyphenol extracts and 9 (B) vitamin C extracts from domestically processed broccoli.

10 Figure 5. The changes in the TEAC value of carotenoid and tocopherol extracts from 11 domestically processed broccoli. 


\section{$1 \quad$ List of Tables}

2 Table I. Glucosinolate content ( $\mu \mathrm{mol} / \mathrm{g}$ dry weight) in fresh, steamed and water-cooked 3 broccoli.

4 Table II. Distribution (mean $\pm \mathrm{SD}$ ) of compounds analysed in fresh and domestically5 processed broccoli $(\mathrm{mg} / 100 \mathrm{~g})$.

6 Table III. Antioxidant activity (mmol Trolox/100 g) of polyphenol, vitamin C and 7 carotenoid/tocopherol extracts from fresh, water-cooked and steamed broccoli (mean \pm SD). 